\title{
THE EFFECT OF RELIGIOSITY MODERATION TO HALAL LOGO ON INCREASING MUSLIM PURCHASE INTENTION IN JAKARTA
}

\author{
Notodisurjo Pravira Sisyawan*, Syah Tantri Yanuar Rahmat, Anindita Rina \\ Faculty of Economic and Business, University of Esa Unggul, Indonesia \\ *E-mail: pravira.notodisurjo@gmail.com
}

\begin{abstract}
Studying on sales of products that have Halal Logo are very attractive in Indonesia, putting Halal Logo on products are expected to improve consumers purchase intention. This study examines the effect of religiosity moderation to halal logo increasing purchase intention especially in Muslims consumer. From the results of several previous studies on the concept of halal and Muslim ways, there are three proposed variables, namely halal logo, religiosity and purchase intention. Where products with a halal logo which is moderated by religiosity will increase purchase intention of Muslims consumer. The data in this study were collected through online surveys using a google form questionnaire with a total of 120 Muslim consumers living in Jakarta with ages ranging from seventeen to forty years. The study was conducted in November 2018 using a research method that is moderate with a comparative approach of two groups of data samples to see the relationships between variables. Data analysis method use in this study is Univariate Analysis of Variance (Univariate ANOVA). The results of this study indicate that products with Halal Logo which is moderated by intrinsic religiosity will increase purchase intention but in the other hand Halal Logo which is moderated by extrinsic Religiosity does not increase purchase intention.
\end{abstract}

\section{KEY WORDS}

Halal, logo, intrinsic religiosity, extrinsic religiosity, purchase intention.

Islam is a religion of grace and peace. Not surprisingly, the number of people who follow Islam increases every year. The CIA World Factbook states that the world Muslim population is 7.4 billion or approximately $23.2 \%$ of the world population. The PEW Research Center states that the Muslim population has grown by an average of $1.5 \%$ since 2019 and will reach 2.2 billion in 2030. Indonesia as a country that has 260 million inhabitants is in the fourth position on the world largest population; with a Muslim population at $87.2 \%$ Indonesia certainly has a consumer segment for halal products that are very high. The large number of Muslim populations has an impact on increasing variations in halal products, such as food, beverages, clothing, medicines, hotels, banks, or property. In addition, Muslim awareness of the importance of choosing products that have halal products will certainly also affect the interest in buying products. Halal products are products that have been granted a halal certificate by the relevant institution and are given a sign through the halal logo on the packaging. In Indonesia, halal certification is issued by the halal product guarantee agency namely Badan Penyelenggara Jaminan Produk Halal (BPJPH) of Indonesia Ministry of Religion.

Consumer decisions to buy a halal product are related to Religiosity. A person's religiousness refers to the level of individual adherence to his religion (Worthington et al, 2003). This can be measured by involvement in religion as a means and purpose. religiosity as a means refers to extrinsic attributes, while religiosity as a goal refers to Intrinsic attributes (Mokhlis, 2009). This study conducts to prove the moderation of religiosity on halal logo will increase Purchase Intention to Muslim consumers.

\section{LITERATURE REVIEW}

The majority of Muslims pay attention to the contain in the products they are going to buy, the existence of halal logos on the products will increases the intention of Muslims to buy a product. Muslim consumers are careful in choosing products, first they will ensure that the 
products to be purchased are good and halal (Jonathan A.J. Wilson \& Liu, 2011). The research conducted by (Nasution \& Rossanty, 2018) shows halal logo increasing the purchase of imported frozen food. Muslim consumers are afraid to consume derivative products from meat using packaging originating from non-halal materials. Religious values affect consumers intentions to consume meat and derivative products (Bonne, 2008). The hotel manager feels that halal certification is very dominant in the hotel industry, because it encourages the importance of restaurant managers having knowledge of food boundaries, understanding and spiritual practices of Muslims (Marzuki et al., 2012).

Product certification as a halal product not only guarantees Muslims for what they eat or consume in accordance with Islamic law but also gives trust to producers to meet standards (Arif \& Ahmad, 2011). The halal logo has become a common tool for convincing Muslims in several countries. According to Peraturan Menteri Perdagangan Republik Indonesia Nomor 31 tahun 2011 food labels are descriptions of food in the form of pictures, writing, or a combination of both, and other forms that are inserted or pasted on the packaging. Halal products are products that have been granted a halal certificate by the relevant institution and given a sign through a halal label in the form of a halal logo on the packaging. Halal Logo is a statement that is permitted about food packages to indicate the status of a product. In Indonesia, halal certification is issued by the Halal Product Guarantee Agency namely Badan Penyelenggara Jaminan Produk Halal (BPJPH) of Indonesia Ministry of Religion.

Religion and religiosity are considered a taboo topic in the field of marketing (Khraim, 2010). However, in the marketing literature there are several studies on this topic. Religion is an important cultural component. Roles in consumer behavior cannot be ignored (M. Patel, 2012). According to Worthington et al. (2003), Religiosity agrees with the level of individual participation in religion. This can be considered in terms of participation in religion as a means and purpose. Religiosity as a means refers to extrinsic religiosity attributes, while as a goal, refers to Intrinsic attributes (Mokhlis, 2009). For studies of halal purchases, religion and religion can be added to the model (Junos, 2012). According to Ajzen (2001), a person's normative trust represents a recognized expectation from an individual or an important reference group of that person. Buying halal products can be caused by subjective norms. When a consumer feels pressure from their reference, he will act like the pressure group (Wilson \& Grant, 2013).

Highly religious people are more dogmatic than less religious people, which makes very religious people buy food that is in harmony with their religion. Religiosity will affect the likes and dislikes of Muslim customers (Ateeq-ur-Rehman \& Shabbir, 2010). Newaz et al. (2016) said religiosity has a positive effect on Muslim consumers. Regarding their religion, Muslims will choose foods that have a halal label compared to those that do not have a halal label. Research conducted by (Soon \& Wallace, 2017) found attitudes to be a significant factor in influencing the intention to buy halal food.

According to "Theory of Planned Behavior", the consumer's intention to buy any product depends entirely on three main factors, namely attitudes, norms and perceptions of the subject. According to Ajzen and Fishben (1980), subjective norms can also be termed attitudes toward certain behaviors. In other words, this is the individual's perception of social factors that influence individuals to do or not do certain behaviors. In terms of purchasing halal products, trust in consumer behavior will determine whether the person will buy halal products or not. halal awareness, halal certification and halal marketing concepts towards the intention to purchase halal food (Rajagopal et al., 2011). Determination of purchase intentions when buying halal products is based on high and low consumer religious beliefs, because this religiosity is a basic principle that influences purchase intentions (Alam \& Sayuti, 2011).

\section{HYPOTHESIS DEVELOPMENT}

Relationship between Halal Logo and Purchase Intention. Halal is an Arabic word that means legal, permitted, or permitted (Wilson \& Liu, 2010). This implies that Muslims must consume or buy products that are permitted by their religion. Muslim consumers are required by their religion to only consume halal products. Therefore, when buying products, they are 
looking for halal logos certified by religious authorities. The study conducted by (Aziz \& Vui, 2012) shows that the purchase intention of halal food products is influenced by awareness and halal certification. Muslim consumers are careful in choosing products, they first ensure that the products to be purchased are good and halal (Jonathan A.J. Wilson \& Liu, 2011). Research conducted by (Nasution \& Rossanty, 2018) shows halal logos increasing the purchase of imported frozen food.

H1: Halal logo increases Purchase Intention.

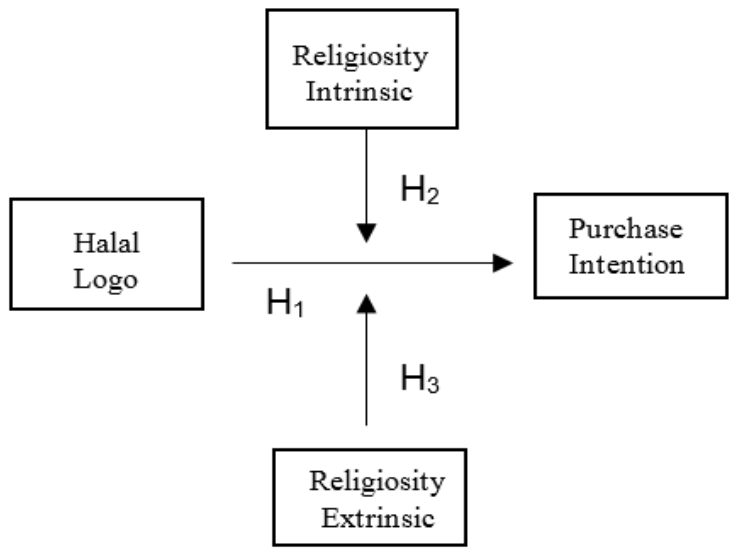

Figure 1 - Conceptual framework

The relationship between halal logo which is moderated by religiosity to increase purchase intention. Muslims will choose foods that have a halal label than those who do not have a halal label. Research conducted by (Soon \& Wallace, 2017) found that attitudes are a significant factor in influencing the purchase intention of halal food. According to Ajzen (2001), normative beliefs represent perceived behavioral expectations of individuals or important reference groups of the person. Buying halal products can be influenced by subjective norms. When a consumer feels pressure from their reference, he will act like the pressure group (Wilson \& Grant, 2013).

H2: Halal Logo which is moderated by Religiosity Intrinsic increases Purchase Intention; Intention.

H3: Halal Logo which is moderated by Religiosity Extrinsic increases Purchase

\section{METHODS OF RESEARCH}

This study examines the effect of religiosity moderation to halal logo increasing purchase intention especially in Muslims consumer. Data in this study were collected through online surveys using google form questionnaire, with the number of respondents as many as 120 Muslim consumers living in Jakarta with ages ranging from 17 to 40 years. The study was conducted in November 2018 using a research method that is moderate with a comparative approach of two groups of data samples to see the relationships between variables. Data analysis method use in this study is Univariate Analysis of Variance (Univariate ANOVA). The sample measurement method use is Likert scale, where respondents are asked to choose one to five of scale intervals for their choices ranging between strongly agree to strongly disagree for the statement that best fits the respondent. The results of the analysis are interpreted, and the final steps are summarized and given suggestions.

There is one independent variable in this study, namely Halal Logo, one moderating variable namely Religiosity which has Intrinsic and Extrinsic attributes, and one dependent variable namely Purchase Intention. Measurement of the Halal Logo and Purchase Intention variables using (Malhotra, 2010), while the measurement of the Religiosity variable using dimensions (Worthington et al., 2003) Religious Commitment Inventory (RCl 10) consisting of Intrinsic Religiosity and Extrinsic Religiosity. Questionnaire was used to obtain data from 
respondents. The original questionnaire used English which was then translated into Indonesian. Validity test and reliability test is done by using the initial 30 data.

Validity test is done by Confirmatory Factor Analysis, by looking at the value of KaiserMeyer-Olkin Measure of Sampling (KMO) and Measures of Sampling Adequacy (MSA). In this test the value obtained must be greater than 0.500 which means that factor analysis is suitable for use, and can be further processed (Doll et al., 1994). The Halal Logo scale consists of 5 statements and there are 2 invalid statements because there are more than one matrix component, invalid statements are X1 (0.650) and X5 (0.566), the Intrinsic Religiosity scale consists of 6 statements and all are valid, the Extrinsic Religiosity scale consists of 3 statements and all are valid, while the scale of Purchase Intention consists of 4 statements and all are valid. Cronbach Alpha value reliability test is greater than $>0.5$ which means reliable (Sugiyono, 2012), in the other word it can be said that the indicators of all variables can be trusted as a data collection tool in this study. The next phase, we were managing the data using the Univariate Analysis of Variance analysis method. Univariate ANOVA was considered able to explain the analysis of variability in two sample groups in detail.

\section{RESULTS OF STUDY}

This study examines the effect of religiosity moderation to halal logo increasing purchase intention especially in Muslims consumer. There are two moderations of Religiosity given, Intrinsic and Extrinsic. Where the results obtained indicate that the moderation of intrinsic religiosity towards halal logo increases purchase intention, but the extrinsic religiosity moderation has no effect on purchase intention. Data analysis was performed using Univariate ANOVA where halal logo, intrinsic religiosity and extrinsic religiosity are grouped into two groups to be compared. Grouping scale can be seen below:

\begin{tabular}{|c|c|c|}
\hline Halal Logo & $\mathrm{HL}$ Code $=1$ & High Halal Logo Perception \\
\hline & HL Code $=2$ & Low Halal Logo Perception \\
\hline \multirow[t]{2}{*}{ Religiosity Intrinsic } & RI Code $=1$ & High Religiosity Intrinsic \\
\hline & RI Code $=2$ & Low Religiosity Intrinsic \\
\hline \multirow[t]{2}{*}{ Religiosity Extrinsic } & $\mathrm{RE} \mathrm{Code}_{\mathrm{g}}=1$ & High Religiosity Extrinsic \\
\hline & $\mathrm{RE} \mathrm{Code}_{\mathrm{d}}=2$ & Low Religiosity Extrinsic \\
\hline
\end{tabular}

The table below explains the results of Univariate Anova on the moderation of fix factor Intrinsic Religiosity and Halal Logo on dependent variable Purchase Intention. The Confidence Interval used is $95 \%$ or if the Sig value is $<0.05$ then it is said to be significant.

\begin{tabular}{|c|c|c|c|c|l|}
\hline Parameter & B & $\boldsymbol{\beta}$ & $\mathbf{t}$ & Sig & \multicolumn{1}{|c|}{ Description } \\
\hline Intercept & $\beta 0$ & 0.350 & 2.097 & 0.038 & significant \\
\hline HL_Code=1 & $\beta 1$ & 0.010 & 0.039 & 0.969 & Not Significant \\
\hline [HL_Code=1]*[RI_Code=1] & $\beta 2$ & -0.782 & -3.196 & 0.002 & Significant \\
\hline [HL_Code=2]*[RI_Code $=1]$ & $\beta 3$ & -0.628 & -2.569 & 0.011 & Significant \\
\hline
\end{tabular}

$\mathrm{H} 1$ : Halal Logo does not increase Purchase Intention;

H2: Halal Logo which is moderated by Intrinsic Religiosity increase Purchase Intention.

Calculation of test results for the Halal Logo relationship model which is moderated by Intrinsic Religiosity towards Purchase Intention can be seen below:

\begin{tabular}{|c|l|l|l|l|}
\hline & HL_Code=1 & HL_Code=2 & Difference & Hypothesis \\
\hline RI_Code=1 & $\beta 0+\beta 1-\beta 2$ & $\beta 0-\beta 3$ & $\beta 1-\beta 2+\beta 3$ & \\
\hline RI_Code= & $\beta 0+\beta 1$ & $\beta 0$ & $\beta 1$ & $\mathbf{H}_{2} \mathbf{a}$ \\
\hline Difference & $-\boldsymbol{\beta 2}$ & $-\beta 3$ & & \\
\hline Hypothesis & $\mathbf{H}_{2} \mathbf{b}$ & $\mathbf{H}_{2} \mathbf{c}$ & & \\
\hline
\end{tabular}

H2a: Specifically, for groups of respondents with low Intrinsic Religiosity, Respondents who have a high perception of Halal Logo have a higher Purchase Intention than the group of respondents who have a low perception of Halal Logo. 
H2b: Specifically, for groups of respondents who have a high perception of Halal Logo, respondents with low Intrinsic Religiosity have Purchase Intention that is higher than the group of respondents with high Intrinsic Religiosity.

H2c: Specifically, for groups of respondents who have a low perception of Halal Logo, respondents with low Intrinsic Religiosity have Purchase Intention that is higher than the group of respondents with high Intrinsic Religiosity.

The table below explains the results of Univariate Anova on moderating fix factor Extrinsic Religiosity and Halal Logo on dependent variable Purchase Intention. The Confidence Interval used is $95 \%$ or if the Sig value is $<0.05$ then it is said to be significant.

\begin{tabular}{|c|c|c|c|c|l|}
\hline Parameter & $\mathbf{B}$ & $\boldsymbol{\beta}$ & $\mathbf{t}$ & Sig & \multicolumn{1}{|c|}{ Description } \\
\hline Intercept & $\beta 0$ & 0.220 & 1.198 & 0.233 & Not Significant \\
\hline HL_Code=1 & $\beta 1$ & -0.035 & -0.136 & 0.892 & Not Significant \\
\hline$\left[\mathrm{HL} \_C o d e=1\right]^{*}\left[\mathrm{RE} \_C o d e=1\right]$ & $\beta 2$ & -0.501 & -1.963 & 0.052 & Not Significant \\
\hline$\left[\mathrm{HL} \_C o d e=2\right]^{*}\left[\mathrm{RE} \_C o d e=1\right]$ & $\beta 3$ & -0.315 & -1.234 & 0.220 & Not Significant \\
\hline
\end{tabular}

$\mathrm{H} 1$ : Halal Logo does not increase Purchase Intention;

H3: Halal The logo which is moderated by Extrinsic Religiosity does not increase Purchase Intention.

Calculation of test results for the Halal Logo relationship model which is moderated by Extrinsic Religiosity towards Purchase Intention can be seen below.

\begin{tabular}{|c|c|c|c|c|}
\hline & HL Code $=1$ & HL Code $=2$ & Difference & Hypothesis \\
\hline RE_Code $=1$ & $\beta 0-\beta 1-\beta 2$ & $\beta 0-\beta 3$ & \begin{tabular}{|l|}
$-\beta 1-\beta 2+\beta 3$ \\
\end{tabular} & \\
\hline RE_Code $=2$ & $\beta 0-\beta 1$ & $\beta 0$ & $-\beta 1$ & $\mathbf{H}_{3} \mathbf{a}$ \\
\hline Difference & $-\beta 2$ & $-\beta 3$ & & \\
\hline Hypothesis & $\mathbf{H}_{3} \mathbf{b}$ & $\mathbf{H}_{3} \mathbf{C}$ & & \\
\hline
\end{tabular}

H3a: Specifically, for the group of respondents with low Extrinsic Religiosity, respondents who have a low perception of Halal Logo have a higher Purchase Intention than the group of respondents who have a high perception of Halal Logo.

H3b: Specifically, for groups of respondents who have a high perception of Halal Logo, respondents with low Extrinsic Religiosity have higher Purchase Intention than groups of respondents with high Extrinsic Religious.

H3c: Especially for groups of respondents who have a low perception of Halal Logo, respondents with low Extrinsic Religiosity have higher Purchase Intention than the group of respondents with high Extrinsic Religiosity.

\section{DISCUSSION OF RESULTS}

The results of the first hypothesis test $(\mathrm{H} 1)$ found that the data did not support the hypothesis because from the Univariate Anova test results on the Halal Logo variable which was not moderated by Religiosity, the results were not significant. These results do not support previous studies conducted by Aziz \& Vui (2012); Wilson \& Liu (2011); Nasution \& Rossanty (2018) which states that Halal Logo increases Purchase Intention. This difference may be due to previous studies carried out in different ways, where the variable Religiosity is not separated from Halal Logo. But this result is supported by research conducted by Rajagopal et al. (2011); Alam \& Sayuti (2011) who said halal awareness, halal certification and the concept of halal marketing towards the purchase intention of halal products were based on high and low consumer religious beliefs.

The results of test the second hypothesis $(\mathrm{H} 2)$ found that the data supports the hypothesis because of the results of the Anova Univariate test on Halal Logo variables which is moderated by Intrinsic Religiosity get significant results both for groups of respondents with high or low Intrinsic Religiosity. These results support previous research conducted by Soon \& Wallace (2017); Newaz et al. (2016) which states that Religiosity increases Purchase Intention. This is directly proportional to respondents who have Intrinsic Religiosity for their 
awareness and state that they prefer products with the Halal Logo because the quality is more guaranteed.

The results of test the third hypothesis $(\mathrm{H} 3)$ found that the data did not support the hypothesis because from the results of the Univariate Anova test on the Halal Logo variable which is moderated by Extrinsic Religiosity the results were not significant both for groups of respondents with high or low Extrinsic Religiosity. These results do not support previous studies conducted by Ajzen (2001); Wilson \& Grant (2013); which says that someone will buy a product based on the pressure of their reference, and will act like the pressure group. This difference may be due to previous studies carried out in different ways where Religiosity is not separated in detail between Intrinsic and Extrinsic. In addition, even though environmental factors can affect a person, but stronger religious observance comes from within a person.

\section{CONCLUSION}

There are three results found in this study. First is Halal Logo does not increase Purchase Intention. This means the first hypothesis is not supported, which means Halal Logo that not moderated by Religiosity cannot affects Purchase Intention. Muslim consumers will only pay attention for halal logo when they buy a product if they supported by their Religiosity. Second result is Halal Logo which is moderated by Intrinsic Religiosity increases Purchase Intention. It Means second hypothesis is supported, which means Halal Logo which is moderated by Intrinsic Religiosity affects Purchase Intention. Muslim Consumers that have religiosity from within their own will buy a halal product which is indicate by halal logo. Third result found is Halal Logo which is moderated by Extrinsic Religiosity do not increase Purchase Intention. It means the third hypothesis is not supported, which means Halal Logo which is moderated by Extrinsic Religiosity do not affects Purchase Intention. Muslim consumers who like to do religious activities and gather with devout Muslims only to show their level of faith, don't pay too much attention to the halal logo in the product packaging.

Furthermore, this study found more details result that can be describe as first is specifically for groups of respondents who have a high perception of Halal Logo, respondents with low Intrinsic Religiosity have higher Purchase Intention than the group of respondents with high Intrinsic Religiosity, second result found is specifically for groups of respondents who have a low perception of Halal Logo, respondents with low Intrinsic Religiosity have a higher Purchase Intention than the group of respondents with high Intrinsic Religiosity. Third result found is specifically for the group of respondents with low Intrinsic Religiosity, Respondents who have a high perception of Halal Logo have a higher Purchase Intention than the group of respondents who have a low perception of Halal Logo. Fourth result found is specifically for groups of respondents with low Extrinsic Religiosity, respondents who have a low perception of Halal Logo have a higher Purchase Intention than the group of respondents who have a high perception of Halal Logo. Fifth result found is specifically for groups of respondents who have a high perception of Halal Logo, respondents with low Extrinsic Religiosity have higher Purchase Intention than groups of respondents with high Extrinsic Religion. And for the last result is specifically for groups of respondents who have a low perception of Halal Logo, respondents with low Extrinsic Religiosity have higher Purchase Intention than the group of respondents with high Extrinsic Religiosity.

This study has several limitations that can be considered for further study. This study only carried out in Jakarta for all types of halal products and respondents came from Muslim consumers who have an age range between 17 and 40 years. This study uses an online questionnaire as a measuring instrument with the aim of saving time and effort. There is a possibility that respondents fill out the questionnaire with answers that do not match the actual conditions or only fill in based on ideal conditions so that the measurements used do not reflect the actual variables. On the other hand, this study only uses Halal Logo variables, Religiosity and Purchase Intention.

For further study, this research is still very limited, because it is only carried out in Jakarta and respondents come from Muslim consumers who have an age range between 17 and 40 years. This research is also limited to testing the effect of moderating Religiosity on 
Halal Logo on increasing Purchase Intention. Therefore, researchers suggest for the development of further research by adding other variables that can affect Purchase Intention. There are many other variables that can affect Purchase Intention, so the results obtained can be more in-depth.

\section{REFERENCES}

1. Ajzen, I. and Fishbein, M. (1980). Understanding Attitudes and Predicting Social Behaviour, Prentice-Hall, Englewood Cliffs, NJ.

2. Ajzen, I. (2001). Nature and operation of attitudes. Annual Review of Psychology, 52, 2758.

3. Alam, S., \& Sayuti, N. (2011). Applying the theory of planned behavior (TPB) in Halal food purchasing. International Journal of Commerce and Management, 21 No.1, 8-20.

4. Arif, S., \& Ahmad, R. (2011). Food quality standards in developing quality human capital: an Islamic perspective. African Journal of Business Management, 5 No 31, 12242-12248.

5. Ateeq-ur-Rehman, \& Shabbir, M. S. (2010). The relationship between religiosity and new product adoption. Journal of Islamic Marketing, 1(1), 63-69.

6. Aziz, Y. A., \& Vui, C. N. (2012). The role of Halal awareness and Halal certification in influencing non- Muslim's purchase intention. 3rd International Conference on Business and Economic Research, Bandung.

7. Bonne, K. V. I. \&. V. W. (2008). Impact of religion on halal meat consumption decisionmaking in Belgium. International Food \& Agribusiness Marketing, (21(1)), 5-26.

8. Doll, W. J., Xia, W., \& Torkzadeh, G. (1994). A Conformatory Factor Analysis of the enduser Computing Satisfaction Instrument. MIS Quarterly, 18(4), 453-461.

9. Junos, S. (2012). The Halal Product Acceptance Model for the Religious Society/ Nazahah Abd. Rahim, Sutina Junos. Business Management Quarterly Review, 3, No.1, 17-25.

10. Khraim, H. (2010). Measuring Religiosity in Consumer Research From an Islamic Perspective. Economic and Administrative Sciences, 26 No.1, 52-78.

11. M. Patel. (2012). Influence of Religion on Shopping Behavior of Consumers: An Exploratory Study. Abhinav National Monthly Refereed Journal of Research in Commerce \&Management, 1, No.5, 6878.

12. Malhotra, N. K. (2010). Marketing Research: An Applied Orientation. 6th ed. New Jersey: Pearson/Prentice Hall.

13. Marzuki, S.Z., Hall, C.M. and Ballantine, P. . (2012). Restaurant managers' perspectives on Halal certification. Islamic Marketing, 3 No.1, 47-58.

14. Mokhlis, S. (2009). Relevancy and Measurement of Religiosity in Consumer Behavior Research. International Business Research, 2, 75.

15. Nasution, M. D. T. P., \& Rossanty, Y. (2018). Country of Origin as a Moderator of Halal Label and Purchase Behavior. Journal of Business and Retail Management Research, 12(2), 194-201.

16. Newaz, F. T., Fam, K. S., \& Sharma, R. R. (2016). Muslim religiosity and purchase intention of different categories of Islamic financial products. Journal of Financial Services Marketing, 21(2), 141-152.

17. Peraturan Menteri Perdagangan Republik Indonesia Nomor 31 tahun 2011 tentang label pangan. (2011).

18. Rajagopal, S., Ramanan, S., Visvanathan, R. and Satapathy, S. (2011). Halal certification: implication for marketers in UAE. Islamic Marketing, 2 Mo.2, 138-153.

19. Soon, J. M., \& Wallace, C. (2017). Application of theory of planned behaviour in purchasing intention and consumption of Halal food. Nutrition and Food Science, 47(5), 635-647.

20. Sugiyono. (2012). Metode Penelitian Kuantitatif, Kualitatif, dan R\&D. Bandung: Alfabeta, 2012.

21. The Future of the Global Muslim Population | Pew Research Center. (n.d.). Retrieved January 26, 2019, from http://www.pewforum.org/2011/01/27/the-future-of-the-globalmuslim-population/\#/Egypt 
22. Wilson, J. A. J., \& Grant, J. (2013). Islamic marketing: a challenger to the classical marketing canon? Islamic Marketing, 4 No.1, 7-21.

23. Wilson, J. A. J., \& Liu, J. (2010). Shaping the Halal into a Brand? Islamic Marketing, 1, No. 2, 107-123.

24. Wilson, J. A. J., \& Liu, J. (2011). The challenges of Islamic branding: Navigating emotions and halal. Journal of Islamic Marketing, 2(1), 28-42.

25. World - The World Factbook - Central Intelligence Agency. (n.d.). Retrieved January 26, 2019, from https://www.cia.gov/library/publications/the-world-factbook/geos/xx.html

26. Worthington E L, Jr. Wade N G, H. T. L. (2003). The Religious Commitment Inventory-10: Development, Refinement and Validation of a Brief Scale for Research and Counseling. Counseling Psychology, 50, 84-96. 